\title{
Thromboemboliás kockázat pitvarfibrillációban
}

\author{
Csanádi Zoltán dr. \\ Debreceni Egyetem, Klinikai Központ, Kardiológiai és Szívsebészeti Klinika, Debrecen
}

\begin{abstract}
A pitvarfibrilláció növekvő prevalenciájú, az egészségügyi ellátórendszerek számára egyre súlyosabb terhet jelentő probléma, korunk nagy cardiovascularis „járványainak” egyike. Kezelése, különösen a szövődményeként kialakuló thromboembolia megelőzése továbbra is jelentős kihívást jelent az utóbbi években örvendetesen bővülő terápiás lehetőségek ellenére. A jelen összefoglaló a thromboembolia-kockázat felmérésének és a megelőzésnek azokat a lehetőségeit foglalja össze, amelyek minden olyan orvos számára fontosak, akik pitvarfibrilláló beteggel kapcsolatba kerülhetnek. Orv. Hetil., 2016, 157(38), 1511-1515.
\end{abstract}

Kulcsszavak: pitvarfibrilláció, thromboembolia, stroke, antikoaguláns kezelés

\begin{abstract}
Risk of thromboembolism in atrial fibrillation
Atrial fibrillation is considered as one of the cardiovascular pandemics of our days due to its increasing prevalence and the significant burden on healthcare systems. Management, especially prevention of thromboembolism associated with the arrhythmia is still a challenge even with recently available treatment options. Herein, the author reviews the possibilities of risk stratification and stroke prevention, which are important to all medical professionals who potentially encounter patients with this arrhythmia.
\end{abstract}

Keywords: atrial fibrillation, thromboembolism, stroke, anticoagulant therapy

Csanádi, Z. [Risk of thromboembolism in atrial fibrillation]. Orv. Hetil., 2016, 157(38), 1511-1515.

(Beérkezett: 2016. július 22.; elfogadva: 2016. augusztus 11.)

\section{Rövidítések}

DOAC = direkt orális antikoaguláns; ESC = European Society of Cardiology; $\mathrm{OAC}=$ orális antikoaguláns; $\mathrm{PF}=$ pitvarfibrilláció; $\mathrm{TE}=$ thromboembolia $; \mathrm{TEE}=$ transoesophagealis echokardiográfia; TIA = tranzitorikus ischaemiás attak

A pitvarfibrilláció $(\mathrm{PF})$ a leggyakoribb tartós ritmuszavar, ami napjainkban Európában mintegy 6 millió, hazánkban 150-200 ezer embert érint. A lakosság élettartamának és a PF incidenciájának folyamatos növekedése alapján prognosztizálható, hogy a pitvarfibrilláló betegek száma 20-30 éven belül megduplázódik. A ritmuszavar kezelésében a megfelelő kamrafrekvencia és ritmuskontroll biztosítása mellett kiemelt feladat a thromboembolia (TE), ezen belül a stroke megelőzése [1-3]. PF-ben a vérrögképződés predilekciós helye a bal fülcse. Corrado és mtsai [4] 233, terápiás antikoaguláns kezelésben nem részesülő és 48 óránál hosszabb ideje pitvarfibrilláló beteg transoesophagealis (TEE) vizsgálata során 15\%-ban talált bal pitvari thrombust, 1 kivételével valamennyit a bal fülcsében. Ennek oka a mechanikai múködés (kontrakció/relaxáció) kiesése okozta vérpangás, emellett endotheldiszfunkció és lokális hypercoagulobilitas patogenetikai szerepe is felmerül. Méltán nevezték ezért Johnson és mtsai [5] a bal fülcsét az emberi test leghalálosabb függelékének.

A PF legrettegettebb szövődménye a stroke: megközelítőleg minden ötödik ischaemiás szélütés hátterében PF áll. Ismert az is, hogy a PF-hez társuló agyi katasztrófák klinikai megjelenése általában súlyosabb: magasabb mortalitással, nagyobb mértékû rokkantsággal, gyakoribb recidívával kell számolni, mint más etiológia esetén.

A TE-rizikó felmérése ezért elsődleges feladat minden újonnan felismert PF esetén. Az Európai Kardiológiai 
Társaság (European Society of Cardiology - ESC) 2010ben megjelent PF-vezérfonalát [6] már két évvel később, 2012-ben „frissítette”, nem kis részben a TE-profilaxissal kapcsolatosan megjelent újabb adatok miatt [7]. A 2012-es ESC upgrade már tartalmazta az Európában törzskönyvezett új, direkt orális antikoagulánsokkal (DOAC) kapcsolatos ismereteket, valamint a TE-rizikó és a vérzéses rizikó felmérésével kapcsolatos módosításokat. Új, a PF teljes körü kezelésével kapcsolatos európai ajánlások megjelenése ez év őszén várható. A DOACkezeléssel kapcsolatos tudnivalókat jelen lapszámban önálló referátum foglalja össze. Az alábbiakban a rizikófelméréssel kapcsolatos aktuális ismereteket és a TE-profilaxis néhány általános érvényü vonatkozását foglaljuk össze. Fontos hangsúlyozni, hogy az itt részletezett kezelési elvek a nonvalvularis PF-re vonatkoznak, amibe nem tartoznak bele a (hazánkban ritka) reumás eredetű billentyưhibához társuló esetek, továbbá a mübillentyưvel élő betegek.

\section{A thromboembolia kockázatának felmérése}

A jelenleg érvényes ajánlások a PF-nek paroxysmalis, perzisztáló, l évnél hosszabb ideje (long standing) perzisztáló és permanens (elfogadott; a sinusrhythmus viszszaállításának és fenntartásának további kísérletéről az orvos a beteggel egyetértésben lemond) formáját különítik el. További kategóriák az akut (recent onset), az újonnan felismert és a panaszt nem okozó „néma” PF. Ennek az osztályozásnak számos klinikai (és kutatási) relevanciája van, azonban a TE-kockázat szempontjából nem meghatározó. Ugyancsak fontos hangsúlyozni, hogy a TE-rizikó szempontjából a pitvarlebegés is a PFhez hasonlóan értékelendő. A kockázat felmérésekor a betegre vonatkozó demográfiai adatoknak (életkor, nem), társbántalmaknak (hypertonia, cukorbetegség, érbetegség) és anamnesztikus adatoknak van jelentőségük, utóbbiakba beleértve a korábbi stroke/TIA (tranzitorikus ischaemiás attak) eseményt és a myocardialis infarctust.

A TE-kockázat-becslés évek óta ismert és alkalmazott eszköze a $\mathrm{CHADS}_{2}$-score (1. táblázat). A könnyen megjegyezhető és alkalmazható pontrendszerben a PF-hez csatlakozó társbetegségek és állapotok kezdőbetűi alkotják a mozaikszót: a congestiv szívelégtelenség, a hypertonia, a 75 év feletti életkor (age) és a diabetes mellitus 1-1 pontot jelent, míg a korábbi stroke/TIA/egyéb TE előfordulása kettőt $\left(S_{2}\right)$.

A pontrendszer előnye, hogy egyszerü, könnyen megjegyezhető. Ugyanakkor hátránya, hogy az alacsony, 0-1 $\mathrm{CHADS}_{2}$-pontérték nem különíti el megbízhatóan a valóban alacsony rizikójú betegeket, amint azt már a 2010es európai ajánlás is jelezte, megemlítve, hogy a kockázat pontosabb felmérésére használhatóbb lehet a $\mathrm{CHADS}_{2}$ VASc score (1. táblázat), ami a $\mathrm{CHADS}_{2}$-szisztémához képest az alábbi módosításokat tartalmazza:
1. táblázat $\mid \mathrm{A} \mathrm{CHADS}_{2}$ (felül) és a $\mathrm{CHADS}_{2}$-VASc score (alul)

(A különbségek dölttel kiemelve)

\begin{tabular}{lc}
\hline $\begin{array}{l}\text { Kockázati tényezó } \\
\text { (PF-hez társuló betegség/állapot) }\end{array}$ & Pontszám \\
\hline $\begin{array}{l}\text { Congestiv (pangásos) } \\
\text { szívelégtelenség/balkamra-diszfunkció }\end{array}$ & 1 \\
Hypertonia & 1 \\
Age (életkor) 75 év felett & 1 \\
Diabetes mellitus & 1 \\
Stroke/TIA/thromboembolia az anamnézisben & 2 \\
\hline Maximum & 6 \\
\hline
\end{tabular}

Congestiv (pangásos) 1

szívelégtelenség/balkamra-diszfunkció

Hypertonia

1

Age (életkor) 75 év felett

2

Diabetes mellitus

1

Stroke/TIA/thromboembolia az anamnézisben

Vascularis betegség

Age (életkor) 65-74 év

1

Sex category (vagyis női nem)

Maximum

- Az életkort mint rizikótényezőt két részre bontották: a 65 év felettiek 1, a 75 évnél idősebbek 2 pontot kapnak. Ez tükrözi az életkornak mint meghatározó kockázati tényezőnek a szerepét.

- Az érbetegség (akár perifériás, akár coronaria) bekerült az értékelésbe (1 pont).

- A női nem szintén 1 pontos rizikótényező. Jelentősége csak egyéb rizikófaktorral együtt van, önmagában nem indokol kezelést (1. később).

A 2012-es update még egyértelmúbben fogalmaz, amikor kimondja: a TE-kockázatot a $\mathrm{CHADS}_{2}$-VASc pontrendszer alapján kell felmérni, és kizárólag a 0 ponttal rendelkező betegeket nem kell meghatározatlan ideig tartó orális antikoaguláns (OAC) kezelésben részesíteni, valamint azokat, akiknél a női nem az egyedüli rizikófaktor. A többi $\mathrm{CHADS}_{2}$-VASc 1 besorolású beteg esetében a kezelés mérlegelendő, figyelembe véve egyéb körülményeket, különösen a vérzéses rizikót és a beteg életkörülményeit, preferenciáját, a várható complience- $t$ is. $\mathrm{A} \mathrm{CHADS}_{2}$-VASc 2 vagy magasabb score egyértelmúen meghatározatlan idejű kezelést indokol. Érvényesül tehát az a már korábbi ajánlásokban is nyomon követhető tendencia, hogy a pitvarfibrilláló betegek egyre szúkebb körében tekinthetünk el a tartós kezeléstől, lényegében nem azt kell kiválasztanunk, aki antithromboticus kezelést igényel, hanem azt, aki a biztonság feladása nélkül gyógyszermentesen tartható. Ez a szemlélet indokoltnak tünik, ha figyelembe vesszük a különböző pontértékekhez tartozó éves TE-rizikót (2. táblázat), továbbá azt a tényt, hogy krónikus állapotról lévén szó, ezeket a gya- 
2. táblázat Különböző CHADS 2 -VASc pontértékhez tartozó l éves thromboembolia.kockázat antithromboticus kezelés nélkül. A minimális $(0)$ pont esetén évente $0,78 \%$, a maximális $(9)$ pont esetén évente $23,64 \%$ stroke-rizikóval kell számolni

\begin{tabular}{cc}
\hline CHADS $_{2}$-VASc pontérték & Évenkénti stroke/TIA/TE rizikó \\
\hline 0 & 0,78 \\
1 & 2,01 \\
3 & 3,71 \\
4 & 5,92 \\
5 & 9,27 \\
6 & 15,26 \\
7 & 19,74 \\
8 & 21,50 \\
9 & 22,38 \\
\hline
\end{tabular}

korisági mutatókat be kell szorozni a PF fennállásának idejével. Példaképpen, egy 65 éves pitvarfibrilláló beteg, akinek jelenleg a $\mathrm{CHADS}_{2}$-VASc score-ja 2, az elkövetkező 5 év alatt több mint 18\%-os valószínúséggel szenved el TE-eseményt, amennyiben kezelés nélkül marad. A 2012-es dokumentum azt is leszögezi, hogy a PF miatt előírt orális antikoaguláns kezelés vagy K-vitamin-antagonista (2-3 közötti INR-érték beállítására) vagy az új DOAC-szerek valamelyikével végezhető. Aszpirin vagy más vérlemezkegátló szer önmagában nem nyújt megfelelő védelmet, használatuk az antikoaguláns mellett jelentősen fokozza a vérzés rizikóját, ezért azt kerülni kell, kivéve, ha olyan egyértelmú indikációja áll fenn, mint a coronariastent-beültetés utáni állapot.

A fentiekben részletezett terápiás elvek gyakorlati értékét a közelmúltban megjelent adatok igazolták. Lip és mtsai a dán PF-regiszter adatait elemezve $\mathrm{CHADS}_{2}{ }^{-}$ VASc 0 score esetén nem tudtak kimutatni klinikai előnyt warfarin használatával [8].

$\mathrm{A} \mathrm{CHADS}_{2}$-VASc pontrendszer mellett újabban a TEkockázat szempontjából releváns biomarkereket és a modern képalkotó módszerekkel kimutatható morfológiai eltéréseket is sikerült azonosítani. A RE-LY vizsgálat több mint 6000 betegen végzett post-hoc elemzése során mind a troponin I, mind az NT-proBNP szint összefüggést mutatott a stroke-kockázattal és a vascularis mortalitással [9]. Hasonló analízis az ARISTOTLE vizsgálat közel 15000 betegén megerôsítette, hogy az NTproBNP szint szignifikáns jelzője mind a stroke-előfordulásnak, mind a kardiális halálozásnak, és használata javította a $\mathrm{CHADS}_{2}$-VASc score prediktív értéket [10]. Egy Salt Lake Cityben dolgozó munkacsoport néhány éve arról számolt be, hogy gadolíniummal érzékenyített szív-MR-vizsgálattal a pitvarokban, elsősorban a bal pitvarban kimutatott fibrosis mértéke nemcsak a sinusrhythmus fenntarthatóságát prognosztizálja, hanem a strokekockázattal is szignifikáns összefüggést mutat [11]. Újabban azt is kimutatták, hogy PF-ben a thrombuskép- ződés predilekciós helyének számító bal fülcse szív-CTvizsgálattal meghatározott alakja és mérete szintén öszszefügg a TE kockázatával [12]. Mindezek alapján valószínüsíthető, hogy a jelenleg használt, elsősorban a társbetegségeken alapuló kockázatbecslés pontossága biomarkerek és képalkotó vizsgálatok során nyerhető paraméterekkel tovább javítható, ezek várhatóan beépülnek majd a rizikóbecslés újabb sémáiba.

\section{Antikoaguláns kezelés és vérzéses kockázat}

Minden antithromboticus kezelés egyben fokozott vérzéskockázatot jelent. Az alvadásgátlók szedéséhez társuló vérzéses szövődménytől való félelem - mind az orvosok, mind a betegek részéról - az egyébként indokolt kezelés elmaradásának vagy az elindított kezelés megszakításának leggyakoribb oka. Ez a rosszul értelmezett defenzív gondolkodás, hogy tudniillik ,a stroke a beteg, a vérzés az orvos hibája”, ma is sok-sok elkerülhető TEesemény, egyéni tragédia okozója világszerte. Fontos, hogy a beteg is megértse, tudja, hogy miért vállalja a kezeléssel járó kockázatot és kellemetlenséget, az milyen egészségügyi katasztrófa elkerülését, megelőzését biztosítja.

Az orális alvadásgátló kezeléshez társuló kockázat személyre szabott megítélésére, számszerüsítésére a 2010es európai ajánlásban már megjelent a HAS-BLED score (3. táblázat) anélkül, hogy gyakorlati útmutatással szolgált volna a vérzéses és a TE-rizikó együttes értékelésére vonatkozóan. A 2012-es update ebből a szempontból is továbblépést jelent. Kimondja, hogy emelkedett vérzéses kockázatot a 3 pont vagy azt meghaladó HAS-BLED score jelez, ami azonban nem ellenjavallja az OAC-kezelést. Sőt a kockázati tényezők közötti átfedéséből (hypertonia, életkor, korábbi stroke) következően, ezek a betegek TE szempontjából is többnyire emelkedett rizikójúak. A vérzéses rizikót a befolyásolható tényezők lehetőség szerinti kiiktatásával és kezelésével kell csökkenteni (haemostasisra ható egyéb gyógyszerek, vérlemezkegátlók lehetőség szerinti elhagyása, alkoholtilalom, társbetegségek, cukorbetegség, hypertonia megfelelő kezelése stb.), továbbá az előírt antikoaguláns szer és adagolásának megválasztásánál kell figyelembe

3. táblázat |A HAS-BLED pontrendszer a vérzéskockázat felmérésére

\begin{tabular}{lc}
\hline Kockázati tényező, társbetegség & Pontszám \\
\hline Hypertonia & 1 \\
Abnormális vese/máj funkció & $1 / 2$ \\
Stroke (anamnesztikus) & 1 \\
Bleeding (vérzés) -hajlam vagy korábbi manifeszt vérzés & 1 \\
Labilis INR & 1 \\
Elderly (időskor; 65 év felett) & 1 \\
Drugs/alkohol (NSAID, aszpirin, antikoaguláns) & $1 / 2$ \\
\hline Maximum & 9 \\
\hline
\end{tabular}


venni, erre az újabban kibővült antithromboticus gyógyszerválaszték lehetőséget teremt. Azokban a ritka esetekben, amikor az orális antikoagulánsok mindegyike kontraindikált, mérlegelendő a bal fülcse eszközös zárása, ami néhány éve hazánkban is elérhető transzkatéteres beavatkozás.

\section{Néma PF és stroke-kockázat; monitorozási stratégiák stroke elött és után}

A pitvarfibrilláló betegek egy pontosan nem ismert, de biztosan nem elhanyagolható hányadában a ritmuszavar semmilyen panaszt, tünetet nem okoz és véletlenül, szürés vagy egyéb indikációval végzett EKG-vizsgálattal, rosszabb esetben TE-esemény kapcsán kerül felismerésre. A PF időben történő kimutatásával és indokolt esetben a megfelelő antithromboticus terápia elindításával a cardiogen stroke előfordulását jelentősen csökkenteni lehetne. Populációszintü szürés a potenciálisan veszélyeztetettek nagy számából adódóan a gyakorlatban nehezen kivitelezhető. Ugyanakkor fontos és reális feladat a rizikófaktort jelentő társbetegségek, hypertonia, cukorbetegség, szívelégtelenség miatt orvoshoz forduló, továbbá a 75 év feletti betegek ritmusának rendszeres ellenőrzése, hiszen a PF ezekben az esetekben jár emelkedett TE-kockázattal. Ennek tudatosítása a háziorvosok, üzemorvosok, belgyógyászok, kardiológusok és nem utolsósorban a betegek körében fontos feladat a stroke megelőzéséért folytatott közös küzdelemben.

Hasonlóan fontos és nem egyszerü feladat a PF dokumentálása cryptogen stroke-ot túlélőkön. Ezeknek a betegeknek egy részében az etiológia szintén a fel nem ismert PF. A ritmuszavar igazolása ilyenkor is fontos a további kezelés, az ismétlődő TE megelőzése szempontjából. Dokumentált PF-epizód esetén ugyanis az orális antikoaguláns szedése vérlemezkegátló kezelés helyett abszolút indikációt képez.

A néma PF EKG-dokumentálása kihívást jelentő feladat a ritmuszavar paroxysmalis formáiban. A diagnózis esélye a monitorozás intenzitásával és időtartamával arányosan növekszik. A CRYSTALL AF vizsgálatban 441, cryptogen stroke-ot túlélő (40 éven felüli) beteget randomizáltak 1:1 arányban hagyományos arrhythmiamonitorozásra (sorozat-EKG, 24 órás Holter) vagy a bőr alá implantálható Reveal XT (Medtronic, Minneapolis, MN, Amerikai Egyesült Államok) monitor (implantable loop recorder - ILR) beültetésre [13]. PF-epizódot a beültetett monitorral a betegek $8,9 \%$-ában, illetve $12,4 \%$-ában sikerült detektálni 6 hónapos, illetve 1 éves utánkövetés során. A hagyományos technikákkal ez az arány 1,4\%, illetve $2 \%$ volt. A beültethető monitor legújabb típusa (LINQ) már olyan kisméretű, hogy egy fecskendőhöz hasonló eszközből (1. ábra) néhány mm-es bőrmetszés után a bőr alá lehet injektálni egy 5 perces, fekvőbetegellátást nem igénylő, minimálisan invazív beavatkozással. Szélesebb körű elterjedését elsősorban az ára korlátozza.
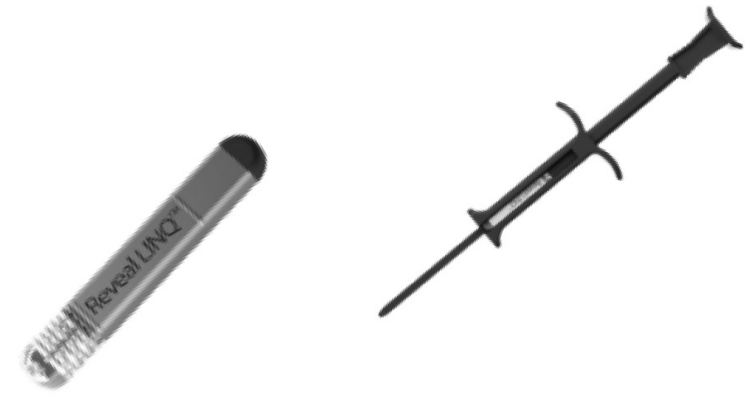

1. ábra

Reveal LINQ beültethető arrhythmiamonitor. Bal oldalon a monitor látható, jobb oldalon az implantálóeszköz, aminek hegyes vége a bőrön történő áthatolást, majd a bőr alatti alagút kialakítását segíti. A betöltött monitor egyetlen mozdulattal injektálható a subcutan alagútba

\section{PF és néma cerebralis ischaemia}

A PF-hez köthető cerebralis embolisatio nem csak manifeszt, klinikai tüneteket okozó stroke képében jelentkezhet. Jóval gyakrabban fordul elő a klinikailag néma, csak képalkotó eljárásokkal felderíthető embolisatio. Egy közelmúltból származó metaanalízis 11 közlemény 5317 olyan betegének adatait összesítette (életkor 50-84 év), akiknek nem volt korábban lezajott klinikai stroke/TIA eseményük [14]. Azt találták, hogy a PF bármely formájának jelenléte 2,6-szeresére növeli annak az esélyét, hogy képalkotó vizsgálattal cerebralis ischaemiás laesio detektálható. A pitvarfibrilláló betegek között diffúziós MR-vizsgálattal 40\%-ban, CT-vizsgálattal 22\%-ban találtak laesiót. Ezeknek a néma ischaemiás laesióknak a jelentősége egyelöre pontosan nem ismert, de 2 lehetséges következményt már most is feltételeznek. Egyrészt szerepük lehet abban, hogy a PF-hez társuló stroke magasabb mortalitású és súlyosabb mértékű funkciózavart hagy maga után, mivel az akut esemény nem intakt, hanem már diffúz laesiókkal „előkezelt” agyi struktúrákat érint. Másrészt szerepük lehet a hosszú időn át pitvarfibrilláló betegeken megfigyelt kognitív funkcióromlás, nemritkán dementia kialakulásában. Egy frissen közölt metaanalízis 8 vizsgálat közel 78000 betegének adatait összesítette (életkor: 61-84 év), akiknek kognitív funkciója a vizsgálat kezdetén normális volt [15]. A 7,7 év átlagos utánkövetés során a betegek 15\%-a pitvarfibrillált, közülük 6,5\%-ban váltak demenssé.

Anyagi támogatás: A közlemény megírása anyagi támogatásban nem részesült.

A szerző a cikk végleges változatát elolvasta és jóváhagyta.

Érdekeltségek: A szerzőnek nincsenek érdekeltségei. 


\section{Irodalom}

[1] Fazekas, T., Csanádi,Z. (eds.): Treatment of arrhythmias: clinical evidence. [A szívritmuszavarok kezelése: klinikai bizonyítékok.] Medicina Könyvkiadó, Budapest, 2004. [Hungarian]

[2] Csanádi, Z., Fazekas, T., Varró, A.: Non-pharmacologic treatment of atrial fibrillation. [A pitvarfibrilláció kezelésének nem farmakológiai lehetőségei.] Orv. Hetil., 2003, 144(26), 12791289. [Hungarian]

[3] Fazekas, T., Csanádi,Z., Varró, A.: Drug therapy of atrial fibrillation. [A pitvarfibrilláció gyógyszeres kezelése.] Orv. Hetil., 2003, 144(24), 1199-1206. [Hungarian]

[4] Corrado, G., Beretta, S., Sormani, L., et al.: Prevalence of atrial thrombi in patients with atrial fibrillation/flutter and subtherapeutic anticoagulation prior to cardioversion. Eur. J. Echocardiogr., 2004, 5(4), 257-261.

[5] Johnson, W. D., Ganjoo, A. K., Stone, C. D., et al.: The left atrial appendage: our most lethal human attachment! Surgical implication. Eur. J. Cardiothorac. Surg., 2000, 17(6), 718-722.

[6] Camm, A. J., Kirchbof, P., Lip, G. ., et al.: Guidelines for the management of atrial fibrillation: the Task Force for the Management of Atrial Fibrillation of the European Society of Cardiology (ESC). Eur. Heart J., 2010, 31(19), 2369-2429.

[7] Camm, A.J., Lip, G. Y., De Caterina, R., et al.: 2012 focused update of the ESC guidelines for the management of atrial fibrillation: an update of the 2010 ESC guidelines for the management of atrial fibrillation. Developed with the special contribution of the European Heart Rhythm Association. Eur. Heart J. 2012, 33(21), 2719-2747.

[8] Lip, G. Y., Skjøth, F., Nielsen, P. B., et al.: Non-valvular atrial fibrillation patients with none or one additional risk factor of the $\mathrm{CHA}_{2} \mathrm{DS}_{2}$-VASc score. A comprehensive net clinical benefit analysis for warfarin, aspirin, or no therapy. Thromb. Haemost., $2015,114(4), 826-834$.
[9] Hijazi, Z., Oldgren, J., Andersson, U., et al.: Cardiac biomarkers are associated with an increased risk of stroke and death in patients with atrial fibrillation: a randomized evaluation of longterm anticoagulation therapy (RE-LY) substudy. Circulation, 2012, 125(13), 1605-1616.

[10] Hijazi, Z., Wallentin, L., Siegbahn, A., et al.: N-terminal pro-Btype natriuretic peptide for risk assessment in patients with atrial fibrillation: insights from the ARISTOTLE Trial (Apixaban for the prevention of stroke in subjects with atrial fibrillation.) J. Am. Coll. Cardiol., 2013, 61(22), 2274-2284.

[11] Oakes, R. S., Badger, T. J., Kholmovski, E. G., et al.: Detection and quantification of left atrial structural remodeling with delayedenhancement magnetic resonance imaging in patients with atrial fibrillation. Circulation, 2009, 119(13), 1758-1767.

[12] Di Biase, L., Santangeli, P., Anselmino, M., et al.: Does the left atrial appendage morphology correlate with the risk of stroke in patients with atrial fibrillation? Results from a multicenter study. J. Am. Coll. Cardiol., 2012, 60(6), 531-538.

[13] Sanna, T., Diener, H. C., Passman, R. S., et al.: Cryptogenic stroke and underlying atrial fibrillation. N. Engl. J. Med., 2014, 370(26), 2478-2486.

[14] Kalantarian, S., Ay, H., Gollub, R. L., et al.: Association between atrial fibrillation and silent cerebral infarctions. A systematic review and meta-analysis. Ann. Intern. Med., 2014, 161(9), 650658.

[15] Santangeli, P., Di Biase, L., Bai, R., et al.: Atrial fibrillation and the risk of incident dementia: A meta-analysis. Heart Rhythm, 2012, 9(11), 1761-1768.

(Csanádi Zoltán dr., Debrecen, Móricz Zsigmond krt. 22., 4032 e-mail: drcsanadi@hotmail.com)

\section{ELADÓ}

Orvosi rendelőnek, irodának is alkalmas színvonalasan felújitott 94 m²-es lakás, Budapest XIII. kerületében, a Váci úton (Lehel piac közelében) eladó.

Felszereltség: klíma, 3 fázis, telefon és info-hálózat, beépitett konyhabútor, 2 db WC.

Irányár: 40 millió $\mathrm{Ft}$.

Telefon: 06-20-448-4211 